Saudi Journal of Oral and Dental Research

Abbreviated Key Title: Saudi J Oral Dent Res

ISSN 2518-1300 (Print) |ISSN 2518-1297 (Online)

Scholars Middle East Publishers, Dubai, United Arab Emirates

Journal homepage: https://saudijournals.com/sjodr

\title{
Cytotoxicity of Different Impression Materials
}

\author{
Zbigniew Raszewski (PhD)
}

Spofa Denatal, Markova 238, Jicin Czech Rep.

DOI: $10.36348 /$ sjodr.2020.v05i04.001

| Received: 23.03.2020 | Accepted: 04.04.2020 | Published: 13.04.2020

*Corresponding author: Zbigniew Raszewski

\section{Abstract}

In the moment it is on the market you can meet different types of impression materials differing in their properties and chemical composition. The purpose of the work was to test the cytotoxicity of various types of materials for taking impressions. Material and methods: Samples of 7 different materials (alginates, silicones, impression compound, zinc oxide eugenol, and acrylic) were tested on cell culture Vero CCL-81 in direct contact for a period of 2 hours. Results: One alginate material Elastic Cromo (71.35\%) and Impression Compound (80.42\%) haven't negative influence on the cell cultures. Others significantly inhibit the development of cell cultures (Image 34.25\%, Zetaplus 11.45\%, Stomaflex Putty $8.02 \%$, Repin 10.37\%, FITT 28.92\%). Conclusion: Most of the impression materials tested have cytotoxic properties.

Keywords: impression materials, alginate, silicones, zinc oxide, eugenol, cytotoxic acrylics.

Copyright @ 2020: This is an open-access article distributed under the terms of the Creative Commons Attribution license which permits unrestricted use, distribution, and reproduction in any medium for non-commercial use (NonCommercial, or CC-BY-NC) provided the original author and source are credited.

\section{INTRODUCTION}

At the moment, almost every prosthetic procedure begins with the impression taking. On the market it is possible to find a lot of matrices designed for impressions, differing in chemical composition and properties [1]. The most popular is the alginate impression mass (delivery in powder), which prior to use is mixed with water. The powder is not a homogeneous substance, but a mixture of sodium alginate, gypsum dihydrate, tri-sodium phosphate and diatomaceous earth as filler. The cross-linking reaction consists in converting sodium ions through calcium in the structure of alginate [2].

The second commonly used material for taking impressions for crowns and bridges are silicones. Among them they are two groups of products hardened by additions or condensations. In both cases, it is necessary to mix the two pastes, base mass and catalyst prior to use. The material polymerizes in the temperature of the oral cavity in 3-5 minutes $[1,3]$.

One of the older impression materials is masses based on the reaction of zinc oxide with eugenol. They are used to perform impressions on individual trays for removable dentures $[1,4]$.
The use of thermoplastic materials on the basis of waxes and resins is also necessary for making off the edge of individual trays. They are calling non elastic materials - among which we stand out impression compound. During their heating, the material becomes soft, and after reducing the temperature it is hardening, on the basis of physical process $[1,5]$.

A separate group of impression materials are materials that contain acrylic resins, called tissue conditioners. They are used, among others, to take functional impressions on old prostheses. After mixing the powder with the liquid, there is no chemical reaction, but the absorption of liquid by the powder. The powder is a poly (ethyl methacrylate) and the liquid is a mixture of ethyl alcohol and a plasticizer. The time to remove functional impression from the patient mouth can be longer in this case and takes from minutes to even $1-2$ days $[6,7]$.

The time of contact between each of the above-mentioned materials with the human body is relatively short, which is why they are all included in the 1 st group of medical device. Therefore, before being placed on the market, they must be tested for their biocompatibility. One of the most popular normative tests is the cytotoxicity test on cell cultures. It gives an answer to the question whether the material will interact with the human or not $[1,3]$. 
At the moment, there is a small amount of publications in the literature that cover the cytotoxicity of impression materials. Among them are articles discussing individual groups of materials, for example alginate or silicone materials. This is mainly due to the fact that such materials are for short-term use. Unfortunately, it is not taken into account, that in the case of a dentist, he or she is staying in the long-term effects of this material. Individual groups of materials, examined by various authors, are difficult to compare in a precise way, because they used a variety of research methods and various cell cultures. Therefore, it seems advisable to display the cytotoxicity of various impression materials in one study.
The purpose of this work was to present the cytotoxicity of various impression materials using the MTT method direct contact.

\section{MATERIALS AND METHODS}

The following impression materials were used for testing: alginate: Elastic Cromo (SpofaDental), Image (Dux), condensation silicone Stomaflex Putty (SpofaDental), Zetaplus (Zhermack), based on zinc oxide with eugenol - Repin (SpofaDental), as thermoplastic mas - Impression Compounds (Kerr) and for functional impressions - FITT (Kerr).Compositions of individual materials are presented in Table 1.

Table-1: Composition of impression materials used in the study

\begin{tabular}{|c|c|c|c|}
\hline material & Batch number & Mixing ratio & composition \\
\hline Elastic Cromo & 6627278 & $\begin{array}{l}20 \mathrm{~g} \text { powder/ } 40 \mathrm{ml} \\
\text { water }\end{array}$ & $\begin{array}{l}\text { Diatomic earth, sodium alginate, calcium sulphate dihydrate, } \\
\text { tri sodium phosphate, potassium hexafluorotitanate } \\
\text { aroma, trace of phenolphthalein and thymolphthalein, } \\
\text { propylene glycol }\end{array}$ \\
\hline Image & 6645787 & $\begin{array}{l}18 \mathrm{~g} \text { powder/ } 48 \mathrm{ml} \\
\text { water }\end{array}$ & $\begin{array}{l}\text { Diatomic earth, potassium alginate, calcium sulphate } \\
\text { dihydrate, tetra sodium pyrophosphate, potassium } \\
\text { hexafluorotitanate } \\
\text { Mint aroma, Vaseline oil }\end{array}$ \\
\hline $\begin{array}{l}\text { Stomaflex Putty/ } \\
\text { Stomaflex } \\
\text { Catalyst }\end{array}$ & $\begin{array}{l}\text { putty: } 6877371 \\
\text { catalyst: } 6891786\end{array}$ & $\begin{array}{l}6.5 \mathrm{~g} \text { base } / 0.13 \mathrm{~g} \\
\text { catalyst }\end{array}$ & $\begin{array}{l}\text { Base: Polysiloxanes hydroxy terminated, calcium carbonate } \\
\text { Catalyst: silica, amorphous, crystalline-free, Nonylphenol, } \\
\text { ethoxylated Dibutyltin dilaurate, tetraethyl silicate, ethyl } \\
\text { silicate methyl silicate }\end{array}$ \\
\hline $\begin{array}{l}\text { Zetaplus } \\
\text { Indurent gel }\end{array}$ & $\begin{array}{l}\text { Putty: } 280241 \\
\text { Catalyst:275661 }\end{array}$ & $\begin{array}{l}6.5 \mathrm{~g} \text { base } / 0.13 \mathrm{~g} \\
\text { catalyst }\end{array}$ & $\begin{array}{l}\text { Base: Polysiloxanes hydroxy terminated, crystobalite } \\
\text { Catalyst: trimethoxypropylsilane dioctyltin oxide,ethyl } \\
\text { silicate, carvone }\end{array}$ \\
\hline Repin & & $\begin{array}{l}2 \mathrm{ml} \text { base } / 2 \mathrm{ml} \\
\text { catalyst }\end{array}$ & $\begin{array}{l}\text { Base: Zinc oxide, mineral oil, mint aroma } \\
\text { Catalyst: Eugenol, colophony, oil, amorphous silica, }\end{array}$ \\
\hline $\begin{array}{l}\text { Impression } \\
\text { Compound Red }\end{array}$ & 7050223 & $\begin{array}{l}\text { One compound } \\
\text { melted in water } 55 \mathrm{C}\end{array}$ & Stearic acid, copal resins, talc, iron oxide red \\
\hline FITT & 6989932 & $\begin{array}{l}1.4 \mathrm{~g} \text { powder } / 1 \mathrm{~g} \\
\text { liquid }\end{array}$ & $\begin{array}{l}\text { Powder: poly(ethyl methacrylate), titanium dioxide } \\
\text { Liquid: ethanol, dibutyl phthalate }\end{array}$ \\
\hline
\end{tabular}

\section{Samples preparation}

Samples are mixed according the manufactures information and filled in the acid-resistant steel moulds, $6 \mathrm{~mm}$ in diameter. Ten samples were prepared for each material, of which six were used for further tests. The material was tested 24 hours after preparation of the sample. The alginate materials were stored in polyethylene bags wrapped in a water-infused paper towel to protect them from dry out.

\section{Performed tests}

The impression materials discs test articles were evaluated using the MTT (methylthiazolyldiphenyltetrazolium bromide). The viability assay was performed on VERO CCL-81 cell line. Cells were maintained in MEM medium containing $4 \% \mathrm{FBS}$ in $37^{\circ} \mathrm{C}$ in humified atmosphere enriched by $5 \% \mathrm{CO}_{2}$. Before exposition cells were suspended on 96-well plate in density $1 \times 104$ cells/100 $\mu \mathrm{l}$ in MEM/well. The cells were cultivated for 24 hours to obtained $80 \%$ of confluency, and then were exposed to tested samples, positive and negative controls during
2, 4, and 24 hours. Cell medium was removed and 6x $100 \mu \mathrm{l}$ of the sample, positive control, negative control, blank samples were added to individual wells. After the incubation time with samples, MTT test was applied using in final step 2-isopropanol $(100 \mu \mathrm{g} / \mathrm{l} / \mathrm{well})$ with simultaneous shaking. The absorbance was detected at $570 \mathrm{~nm}$. The negative control (MEM) and blank sample (MEM with 4\% FBS) both demonstrated no cytotoxic effect, thus cell oxidoreductive potential was undisturbed. The positive control (Sodium lauryl sulphate) demonstrated significant cytotoxic impact even after the shortest time of incubation (2h). The viability was less than $20 \%$ after $2 \mathrm{~h}$ exposition and was less than $10 \%$ after 4 and 24 hours.

The test article extract was prepared in $1 \mathrm{x}$ MEM cell growth medium (MEM supplemented with $10 \%$ fetal bovine serum extract) at the sample to extraction medium ratio of $6.0 \mathrm{~cm} 2 / \mathrm{mL}$ and extracted at $37 \pm 1{ }^{\circ} \mathrm{C}$ for $72 \pm 2$ hours. The sample was unchanged by the extraction procedure and the extract was found to be clear and free of particulates. 
Zbigniew Raszewski; Saudi J Oral Dent Res, April, 2020; 5(4): 206-213

\section{DATA ANALYSIS}

According the obtained results the following data analysis was performed. The results obtained from spectrophotometric measurements defined as the viability were calculated according to the formula:

Viability $\%=(100 \times$ OD570 test sample $) / O D 570$ blank

In the equation are used mean values of all measured optical densities at $570 \mathrm{~nm}$ of respective samples. The basic interpretation is based on the following observation, the lower the viability $\%$ value, the higher the cytotoxic potential of the test sample is. If viability is reduced to $<70 \%$ of the blank, it has a cytotoxic potential. The results are shown in Tab 2 for tested samples and in Tab. 3-9 for control samples. Material was tested after 2 hours, because impression procedure takes few minutes and the contact time with patient mouth is very short.

\section{RESULTS}

Results from the performed tests were collected in below tables.

Table-2: Results from the cytotoxicity tests of impression materials after 2 hours

\begin{tabular}{|c|c|c|c|c|c|c|c|}
\hline & Elastic Cromo & Image & Zetaplus & Stomaflex & Impression compound & Repin & FITT \\
\hline & 2 hours & 2 hours & 2 hours & 2 hours & 2 hours & 2 hours & 2 hours \\
\hline Concentration & $100 \%$ & $100 \%$ & $100 \%$ & $100 \%$ & $100 \%$ & $100 \%$ & $100 \%$ \\
\hline $\mathrm{OD}_{570}$ & 0.452 & 0.424 & 0.077 & 0.014 & 0.352 & 0.043 & 0.125 \\
\hline & 0.4 & 0.334 & 0.024 & 0.016 & 0.342 & 0.027 & 0.081 \\
\hline & 0.533 & 0.293 & 0.198 & 0.018 & 0.51 & 0.031 & 0.076 \\
\hline & 0.488 & 0.184 & 0.218 & 0.018 & 0.584 & 0.028 & 0.081 \\
\hline & 0.415 & 0.018 & 0.13 & 0.018 & 0.604 & 0.017 & 0.045 \\
\hline & 0.401 & 0.082 & 0.035 & 0.018 & 0.64 & 0.02 & 0.174 \\
\hline Mean & 0.448 & 0.223 & 0.114 & 0.017 & 0.505 & 0.028 & 0.097 \\
\hline Viability \% & $71.35 \%$ & $34.25 \%$ & $11.45 \%$ & $8.02 \%$ & $80.42 \%$ & $10.37 \%$ & $28.92 \%$ \\
\hline
\end{tabular}

Table-3: Cytotoxicity of control solutions for Elastic Cromo after 2 hours

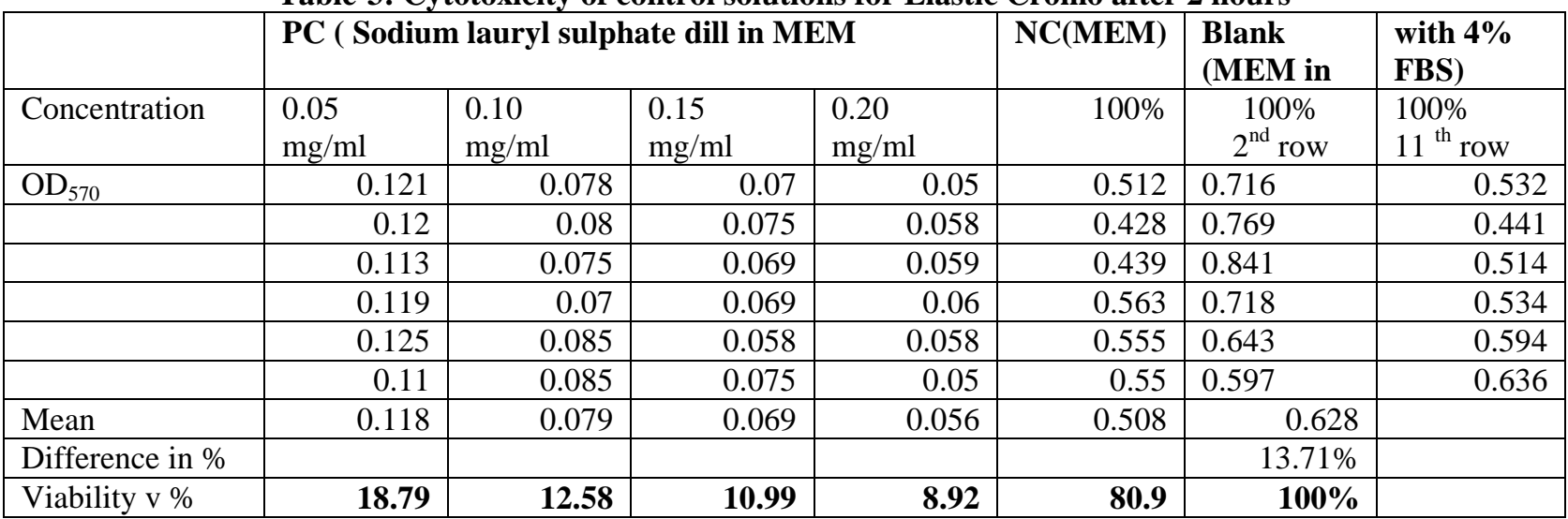

Table-4: Cytotoxicity of control solutions for Image after 2 hours

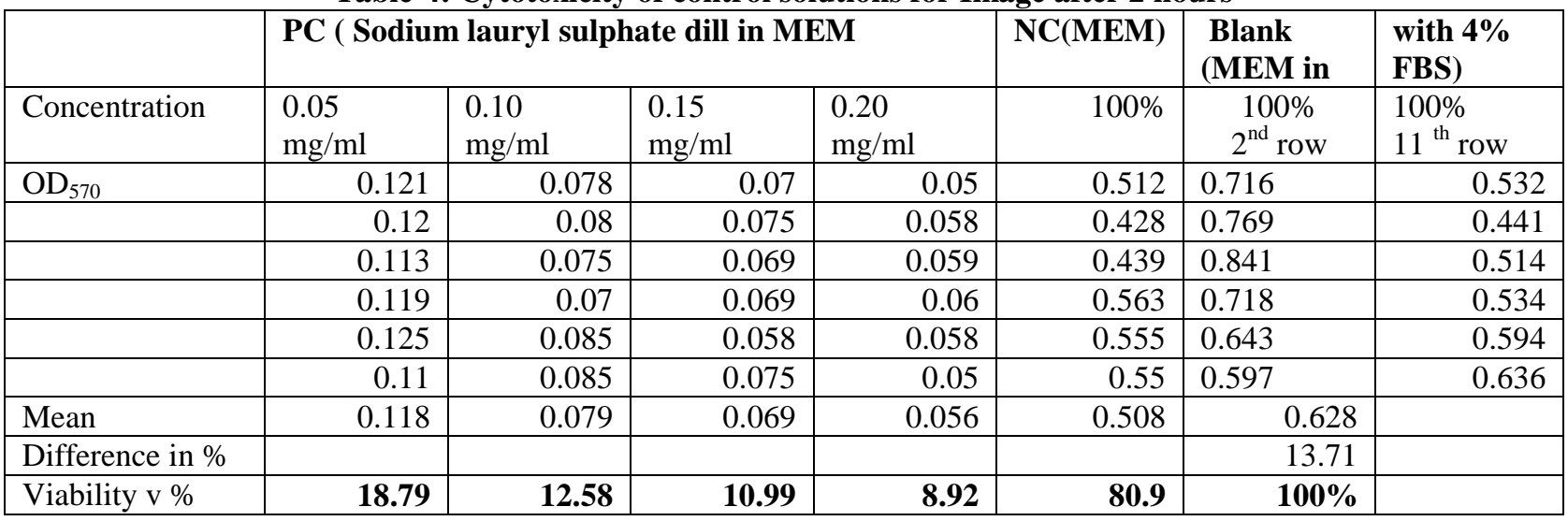


Zbigniew Raszewski; Saudi J Oral Dent Res, April, 2020; 5(4): 206-213

Table-5: Cytotoxicity of control solutions for Zetaplus after 2 hours

\begin{tabular}{|c|c|c|c|c|c|c|c|}
\hline \multirow{2}{*}{ Concentration } & \multicolumn{4}{|c|}{ PC ( Sodium lauryl sulphate dill in MEM } & \multirow{2}{*}{$\begin{array}{r}\text { NC(MEM) } \\
100 \%\end{array}$} & \multirow{2}{*}{$\begin{array}{c}\begin{array}{l}\text { lank } \\
\text { (MEM in }\end{array} \\
100 \% \\
2^{\text {nd }} \text { row }\end{array}$} & \multirow{2}{*}{$\begin{array}{l}\text { with 4\% } \\
\text { FBS) } \\
100 \% \\
11^{\text {th }} \text { row }\end{array}$} \\
\hline & $\begin{array}{l}0.05 \\
\mathrm{mg} / \mathrm{ml}\end{array}$ & $\begin{array}{l}0.10 \\
\mathrm{mg} / \mathrm{ml}\end{array}$ & $\begin{array}{l}0.15 \\
\mathrm{mg} / \mathrm{ml}\end{array}$ & $\begin{array}{l}0.20 \\
\mathrm{mg} / \mathrm{ml}\end{array}$ & & & \\
\hline $\mathrm{OD}_{570}$ & 0.182 & 0.1 & 0.075 & 0.07 & 0.812 & 0.828 & 1.022 \\
\hline & 0.165 & 0.122 & 0.072 & 0.073 & 0.89 & 0.987 & 1.325 \\
\hline & 0.16 & 0.103 & 0.078 & 0.07 & 0.961 & 1.351 & 1.496 \\
\hline & 0.174 & 0.095 & 0.082 & 0.065 & 0.902 & 0.708 & 1.034 \\
\hline & 0.172 & 0.095 & 0.062 & 0.079 & 0.781 & 0.807 & 0.859 \\
\hline & 0.174 & 0.121 & 0.08 & 0.07 & 0.547 & 0.69 & 0.836 \\
\hline Mean & 0.171 & 0.104 & 0.075 & 0.071 & 0.816 & 0.995 & \\
\hline Difference in \% & & & & & & 10.06 & \\
\hline Viability v \% & 17.18 & 10.45 & 7.54 & 7.13 & 81.99 & $100 \%$ & \\
\hline
\end{tabular}

Table-6: Cytotoxicity of control solutions for Stomaflex after 2 hours

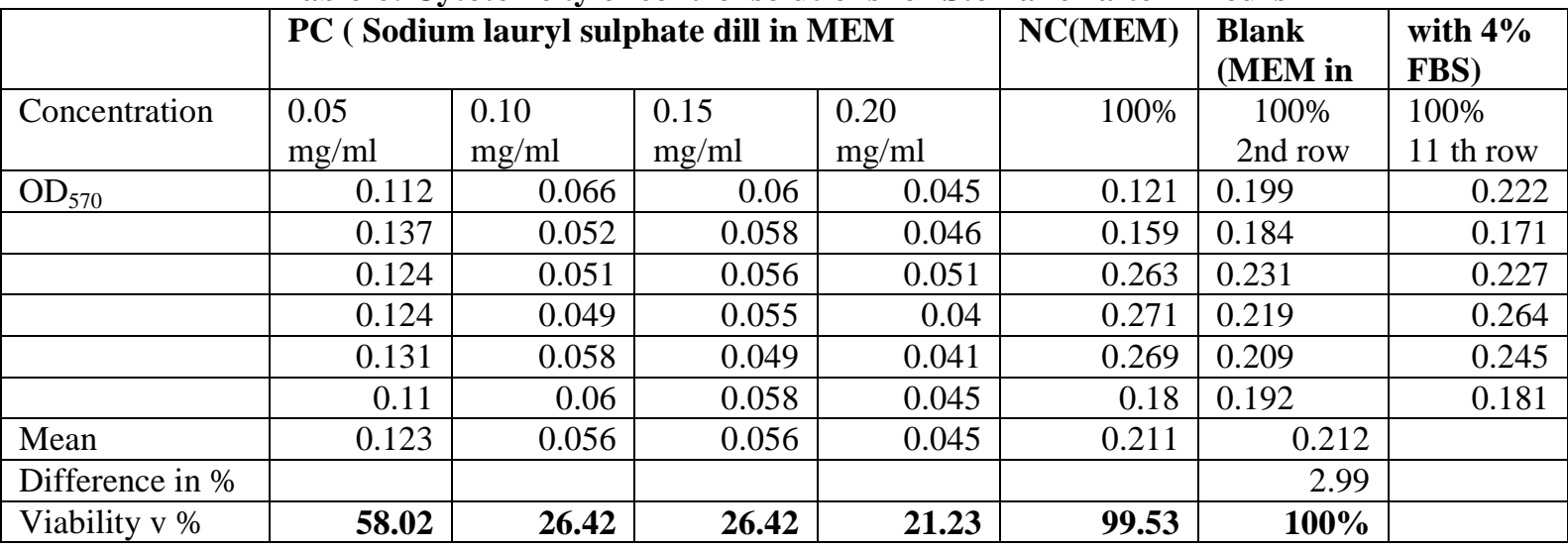

Table-7: Cytotoxicity of control solutions for Impression Compound Red after 2 hours

\begin{tabular}{|c|c|c|c|c|c|c|c|}
\hline \multirow{2}{*}{ Concentration } & \multicolumn{4}{|c|}{ PC ( Sodium lauryl sulphate dill in MEM } & \multirow{2}{*}{$\begin{array}{r}\text { NC(MEM) } \\
100 \%\end{array}$} & \multirow{2}{*}{$\begin{array}{c}\begin{array}{c}\text { Blank } \\
(\text { MEM }\end{array} \\
\begin{array}{c}100 \% 2^{\text {nd }} \\
\text { row }\end{array}\end{array}$} & \multirow{2}{*}{$\begin{array}{l}\text { with } 4 \% \\
\text { FBS } \\
100 \% \\
11^{\text {th }} \text { row }\end{array}$} \\
\hline & $0.05 \mathrm{mg} / \mathrm{ml}$ & $0.10 \mathrm{mg} / \mathrm{ml}$ & $0.15 \mathrm{mg} / \mathrm{ml}$ & $0.20 \mathrm{mg} / \mathrm{ml}$ & & & \\
\hline $\mathrm{OD}_{570}$ & 0.121 & 0.078 & 0.07 & 0.05 & 0.512 & 0.716 & 0.532 \\
\hline & 0.12 & 0.08 & 0.075 & 0.058 & 0.428 & 0.769 & 0.441 \\
\hline & 0.113 & 0.075 & 0.069 & 0.059 & 0.439 & 0.841 & 0.514 \\
\hline & 0.119 & 0.07 & 0.069 & 0.06 & 0.563 & 0.718 & 0.534 \\
\hline & 0.125 & 0.085 & 0.058 & 0.058 & 0.555 & 0.643 & 0.594 \\
\hline & 0.11 & 0.085 & 0.075 & 0.05 & 0.55 & 0.597 & 0.636 \\
\hline Mean & 0.18 & 0.079 & 0.069 & 0.056 & 0.508 & 0.628 & \\
\hline Difference in $\%$ & & & & & & 13.71 & \\
\hline Viability v \% & 18.79 & 12.58 & 10.99 & 8.92 & 90.9 & $100 \%$ & \\
\hline
\end{tabular}

Table-8: Cytotoxicity of control solutions for Repin after 2 hours

\begin{tabular}{|c|c|c|c|c|c|c|c|}
\hline \multirow[b]{2}{*}{ Concentration } & \multicolumn{4}{|c|}{ PC ( Sodium lauryl sulphate dill in MEM } & \multirow{2}{*}{$\begin{array}{r}\text { NC(MEM) } \\
100 \%\end{array}$} & \multirow{2}{*}{$\begin{array}{c}\begin{array}{l}\text { Blank } \\
\text { (MEM in }\end{array} \\
100 \% \\
2^{\text {nd }} \text { row }\end{array}$} & \multirow{2}{*}{$\begin{array}{l}\text { with 4\% } \\
\text { FBS) } \\
100 \% \\
11^{\text {th }} \text { row }\end{array}$} \\
\hline & $0.05 \mathrm{mg} / \mathrm{ml}$ & $0.10 \mathrm{mg} / \mathrm{ml}$ & $0.15 \mathrm{mg} / \mathrm{ml}$ & $0.20 \mathrm{mg} / \mathrm{ml}$ & & & \\
\hline $\mathrm{OD}_{570}$ & 0.15 & 0.05 & 0.05 & 0.04 & 0.373 & 0.412 & 0.285 \\
\hline & 0.149 & 0.059 & 0.05 & 0.035 & 0.248 & 0.425 & 0.241 \\
\hline & 0.138 & 0.5 & 0.056 & 0.035 & 0.3 & 0.269 & 0.247 \\
\hline & 0.138 & 0.061 & 0.059 & 0.041 & 0.26 & 0.261 & 0.228 \\
\hline & 0.14 & 0.059 & 0.059 & 0.045 & 0.29 & 0.219 & 0.22 \\
\hline & 0.127 & 0.055 & 0.055 & 0.046 & 0.248 & 0.18 & 0.254 \\
\hline Mean & 0.14 & 0.056 & 0.055 & 0.04 & 0.287 & 0.27 & \\
\hline Difference in \% & & & & & & 8.98 & \\
\hline Viability v \% & 51.84 & 20.73 & 20.36 & 14.81 & 106.26 & $100 \%$ & \\
\hline
\end{tabular}


Zbigniew Raszewski; Saudi J Oral Dent Res, April, 2020; 5(4): 206-213

Table-9: Cytotoxicity of control solutions for FIIT after 2 hours

\begin{tabular}{|c|c|c|c|c|c|c|c|}
\hline \multirow{2}{*}{ Concentration } & \multicolumn{4}{|c|}{ PC ( Sodium lauryl sulphate dill in MEM } & \multirow{2}{*}{$\begin{array}{r}\text { NC(MEM) } \\
100 \%\end{array}$} & \multirow{2}{*}{$\begin{array}{c}\begin{array}{l}\text { Blank } \\
\text { (MEM in }\end{array} \\
100 \% \\
2^{\text {nd }} \text { row }\end{array}$} & \multirow{2}{*}{$\begin{array}{l}\text { with 4\% } \\
\text { FBS) } \\
100 \% \\
11^{\text {th }} \text { row }\end{array}$} \\
\hline & $\begin{array}{l}0.05 \\
\mathrm{mg} / \mathrm{ml}\end{array}$ & $\begin{array}{l}0.10 \\
\mathrm{mg} / \mathrm{ml}\end{array}$ & $\begin{array}{l}0.15 \\
\mathrm{mg} / \mathrm{ml}\end{array}$ & $\begin{array}{l}0.20 \\
\mathrm{mg} / \mathrm{ml}\end{array}$ & & & \\
\hline $\mathrm{OD}_{570}$ & 0.175 & 0.07 & 0.055 & 0.054 & 0.306 & 0.216 & 0.294 \\
\hline & 0.18 & 0.07 & 0.06 & 0.06 & 0.285 & 0.357 & 0.371 \\
\hline & 0.169 & 0.068 & 0.06 & 0.068 & 0.26 & 0.37 & 0.405 \\
\hline & 0.169 & 0.055 & 0.071 & 0.068 & 0.272 & 0.318 & 0.436 \\
\hline & 0.188 & 0.07 & 0.065 & 0.055 & 0.285 & 0.271 & 0.379 \\
\hline & 0.16 & 0.068 & 0.066 & 0.065 & 0.29 & 0.205 & 0.403 \\
\hline Mean & 0.174 & 0.067 & 0.063 & 0.062 & 0.283 & 0.335 & \\
\hline Difference in $\%$ & & & & & & 13.69 & \\
\hline Viability v \% & 51.88 & 19.97 & 18.78 & 18.48 & 84.37 & $100 \%$ & \\
\hline
\end{tabular}

\section{Quality check of assay}

Elastic Cromo: In case of 2 hour incubation the mean $\mathrm{OD}_{570}$ of blanks is 0.651 and is therefore greater than 0.2 . The left (absorbance values in $2^{\text {nd }}$ row) and the right (absorbance values in $11^{\text {th }}$ row) mean of blanks in the 96-well plate differ from the mean of absorbance of all blanks $\left(\mathrm{OD}_{570}\right)$ by $13.71 \%$, which is less than $15 \%$.

Image: In case of 2 hour incubation the mean $\mathrm{OD}_{570}$ of blanks is 0.628 and is therefore greater than 0.2 . The left (absorbance values in $2^{\text {nd }}$ row) and the right (absorbance values in $11^{\text {th }}$ row) mean of blanks in the 96-well plate differ from the mean of absorbance of all blanks $\left(\mathrm{OD}_{570}\right)$ by $13.71 \%$, which is less than $15 \%$.

Zetaplus: In case of 2 hour incubation the mean $\mathrm{OD}_{570}$ of blanks is 0.995 and is therefore greater than 0.2 . The left (absorbance values in $2^{\text {nd }}$ row) and the right (absorbance values in $11^{\text {th }}$ row) mean of blanks in the 96-well plate differ from the mean of absorbance of all blanks $\left(\mathrm{OD}_{570}\right)$ by $10.06 \%$, which is less than $15 \%$.

Stomaflex Putty: In case of 2 hour incubation the mean OD570 of blanks is 0.212 and is therefore greater than 0.2 . The left (absorbance values in $2^{\text {nd }}$ row) and the right (absorbance values in $11^{\text {th }}$ row) mean of blanks in the 96-well plate differ from the mean of absorbance of all blanks $\left(\mathrm{OD}_{570}\right)$ by $2.99 \%$, which is less than $15 \%$.

Impression Compound Red: In case of 2 hour incubation the mean $\mathrm{OD}_{570}$ of blanks is 0.628 and is therefore greater than 0.2 . The left (absorbance values in $2^{\text {nd }}$ row) and the right (absorbance values in $11^{\text {th }}$ row) mean of blanks in the 96-well plate differ from the mean of absorbance of all blanks $\left(\mathrm{OD}_{570}\right)$ by $13.71 \%$, which is less than $15 \%$.

Repin: In case of 2 hour incubation the mean $\mathrm{OD}_{570}$ of blanks is 0.270 and is therefore greater than 0.2 . The left (absorbance values in $2^{\text {nd }}$ row) and the right (absorbance values in $11^{\text {th }}$ row) mean of blanks in the 96-well plate differ from the mean of absorbance of all blanks $\left(\mathrm{OD}_{570}\right)$ by $8.98 \%$, which is less than $15 \%$.

FITT: In case of 2 hour incubation the mean $\mathrm{OD}_{570}$ of blanks is 0.335 and is therefore greater than 0.2 . The left (absorbance values in $2^{\text {nd }}$ row) and the right (absorbance values in $11^{\text {th }}$ row) mean of blanks in the 96-well plate differ from the mean of absorbance of all blanks $\left(\mathrm{OD}_{570}\right)$ by $13.69 \%$, which is less than $15 \%$.

\section{DATA ANALYSIS}

The viability of the cells after 2 hours application of the test samples Elastic Cromo and Impression Compound Red were $>70 \%$. According to obtain results these two materials haven't cytotoxic effect. For the rest of materials values were lower (Image $34.25 \%$, Zetaplus $11.45 \%$, Stomaflex Putty $8.02 \%$, Repin $10.37 \%$ and FITT $28.92 \%$ ). It means, that these impression materials affected on the cell cultures. The cytotoxic effect of positive control has been proven in all concentrations. Negative control proved no cytotoxic potential.

\section{DISCUSSION}

The cytotoxic effect of alginate impression materials has been described by Pithonat all. For Jeltrate Chromatic Ortho, Orthoprint and Cavex Orthotrace authors indicate, that all alginate impression materials adversely affect cell culture [8].

The same author with another group of researchers in one of his subsequent works has tested a larger group of 14 alginate impression materials. They obtained similar results, all materials inhibited the growth of cell cultures. Some of the tested materials had a stronger impact and other weak (even a 2-times difference) [9].

Sydiskis and Gerhard tested different kinds of impression materials: silicones, alginate and polysulfides, like a conclusion from the research was cytotoxicity off all of them all them and some of the components were also cytotoxic [10]. 
In the case of the current work, one of the tested materials Elastic Cromo does not have cytotoxic properties, whereas the other alginate Image affects cell cultures. The explanation of these facts can be in different composition between these two materials. Elastic Cromo has cherry aroma and Image mint. Essential oils (mint) potentially can inhibit the development of cell cultures [11]. In the composition of alginates, it is possible to find potassium hexafluorotitanate, and zinc compounds, which can also significantly influence cytotoxicity [12].

Most authors are also in agreement about the fact of cytotoxicity of condensation silicones, whereas a harmful factor the by-product of the condensation reaction ethanol is distinguished [13, 14]. Also, tin organic compounds [15], and terta etoxysilane [16], are known for their toxicity.

The exception of the cytotoxicity of condensation silicone ( $\mathrm{C}$ silicones) was published is the work of Jae-Sung Kwon at all, who tested 3 types of addition silicone and one condensation, Xantopren. Obtained results indicate that this material has low influence on the cell cultures during test in extract and with direct contact for all fibroblast [17].

The same Koreans authors noted at the same time, those addition silicones, so far have not been thought to inhibit the growth of cellular culture, and may have an effect on them, due to the surfactants contained in these materials. These compounds are added to the silicone impression materials to reduce their surface tension, when taking the impression in a humid oral environment. As it is known, that silicones belong to strongly hydrophobic compounds [17].

The same authors in the next paper, develops the effect of surfactants on the cytotoxicity of silicone impression materials. They added different concentrations of sodium lauryl sulfate (SLS) to the impression mass (concentration form 0, 1, 2, 4, 8 and 16 $\mathrm{wt} \%$ ). The obtained results indicate that the material after the addition of SLS is cytotoxic. Additionally this substance was isolated by ion chromatography. The eluted amount was directly proportional to the increase in its concentration in the silicone material [18].

F. Boraldi at all demonstrated cytotoxicity of addition silicones (Elite HD, Express Putty and Express Light Body) and polyether (Impregum Penta and Permadyne Penta L) [19].

Results from current study conducted in two C silicones Zetaplus and Stomaflex Putty are in accordance with the literature. Even during short period ( 2 hours) both material are high cytotoxic for VERO CCL-81 cultures.
In literature it is not possible to find any publication about the cytotoxicity of impression compounds, although they belong to one of the oldest materials for taking impressions. The first patents on the use of this type of materials could be found at the beginning of the 20th century [1, 3]. The obtained results indicate that these types of materials are not toxic. They consist of raw materials of natural origin: tree resins, stearic acid, talc. After 2 hours, the viability of cell cultures is quite high and amounts to $80 \%$.

Another group of materials, which are pastes containing zinc oxide and eugenol, they are very widespread in dentistry, and possess very large spectrum of use: to taking impressions, for temporary filling and cementation. They are used because of the bactericidal properties of eugenol [20, 21]. Main mechanisms are that eugenol induces cell lysis through the leakage of protein and lipid in the cell [22].

Material based on $\mathrm{ZnO}$-Eugneol is characterized by strong cytotoxic properties. However, this material does not penetrate the dentin barrier thicker than $0.5 \mathrm{~mm}$, without irritating the pulp [20, 21].

Very interesting is the work of S. D. Meryon, who investigated the cytotoxicity of various types of materials containing zinc oxide and eugenol. The conclusion from his research is that powders of zinc oxide combined with clove oil released significantly more eugenol and were more toxic than pure eugenol with pure zinc oxide [23].

Also, the material Repin (based on $\mathrm{ZnO}$ Eugenol) has strong cytotoxic properties during a 2hour exposure to the cell viability of the cells is $10.37 \%$.

The last of the impression materials tested in our study was FITT, which belongs to the group of acrylics- tissue conditioners. However, it does not have monomers in its composition. In the literature on the cytotoxicity of acrylic resins, as one of the main factors, which can cause cytotoxicity, irritancy or allergies is residual methyl methacrylate [24, 25].

N. Okita at all made investigation about tissue conditioners. They concluded that all tested materials seemed to be more cytotoxic than self-curing denture base resins [26]. The same conclusion was introduced by A. Atay at all, who tested different kinds of soft and hard relining materials. One of them GC belongs to the family of tissue conditioners and possess cytotoxic properties [27].

For the cytotoxicity of this type of material in the main extent can be associated with large concentrations of ethyl alcohol (from 10-20\%), which is rapidly leaching. In the second steps, from the material migrates unconnected plasticizer, it can also adversely 
effect on cell culture [28]. In this study, FITT material also possessed cytotoxic properties (cell survival 28\%)

\section{CONCLUSION}

In current study we tested seven impression materials belonging to different groups, two of them (Elastic Cromo and Impression Compound) did not have cytotoxic properties during a direct contact within 2 hours with cell culture. Others in a strong way were distracting to cells.

\section{Clinical Significance}

During the removal of impressions, the dentist has a contact with various impression materials, which can affect the organs of man in different ways. Therefore, it seems necessary to use appropriate tools of personal protection, such as appropriate gloves, goggles and masks.

\section{REFFERENCE}

1. Punj, A., Bompolaki, D., \& Garaicoa, J. (2017). Dental impression materials and techniques. Dental Clinics, 61(4), 779-796.

2. Cervino, G., Fiorillo, L., Herford, A. S., Laino, L., Troiano, G., Amoroso, G., ... \& Cicciù, M. (2019). Alginate materials and dental impression technique: A current state of the art and application to dental practice. Marine drugs, 17(1), 18.

3. Re, D., De Angelis, F., Augusti, G., Augusti, D., Caputi, S., D'Amario, M., \& D'Arcangelo, C. (2015). Mechanical properties of elastomeric impression materials: An in vitro comparison. International Journal of Dentistry. Volume 2015, Article ID 428286, 8 pages.

4. Myers, G. E., \& Peyton, F. A. (1961). Physical properties of the zinc oxide-eugenol impression pastes. Journal of dental research, 40(1), 39-48.

5. Rubel, B. S. (2007). Impression materials: a comparative review of impression materials most commonly used in restorative dentistry. Dental Clinics of North America, 51(3), 629-642.

6. Ntounis, A., Kamposiora, P., Papavasiliou, G., Divaris, K., \& Zinelis, S. (2015). Hardness Changes of Tissue Conditioners in Various Storage Media: An in Vitro Study. The European journal of prosthodontics and restorative dentistry, 23(1), 915.

7. Monzavi, A., Siadat, H., Atai, M., Alikhasi, M., Nazari, V., \& Sheikhzadeh, S. (2013). Comparative evaluation of physical properties of four tissue conditioners relined to modeling plastic material. Journal of dentistry (Tehran, Iran), 10(6), 506.

8. Pithon, M. M., Santos, R. L. D., Martins, F. O., \& Romanos, M. T. V. (2012). Cytotoxicity of alginate for orthodontic use. Dental Press Journal of Orthodontics, 17(6), 21e1-21e5.
9. Pithon, M. M., dos Santos, R. L., Martins, F. O., \& Romanos, M. T. V. (2009). Cytotoxicity of dental alginates. Revista Odonto Ciência, 24(3), 270-273.

10. Sydiskis, R. J., \& Gerhardt, D. E. (1993). Cytotoxicity of impression materials. The Journal of prosthetic dentistry, 69(4), 431-435.

11. Sun, Z., Wang, H., Wang, J., Zhou, L., \& Yang, P. (2014). Chemical composition and antiinflammatory, cytotoxic and antioxidant activities of essential oil from leaves of Mentha piperita grown in China. PloS one, 9(12).

12. Nandini, V. V., Venkatesh, K. V., \& Nair, K. C. (2008). Alginate impressions: A practical perspective. Journal of conservative dentistry: JCD, 11(1), 37.

13. Chen, S. Y., Chen, C. C., \& Kuo, H. W. (2002). Cytotoxicity of dental impression materials. Bulletin of environmental contamination and toxicology, 69(3), 350-355.

14. Ciapetti, G., Granchi, D., Stea, S., Savarino, L., Verri, E., Gori, A., ... \& Montanaro, L. (1998). Cytotoxicity testing of materials with limited in vivo exposure is affected by the duration of cellmaterial contact. Journal of Biomedical Materials Research: An Official Journal of The Society for Biomaterials, The Japanese Society for Biomaterials, and the Australian Society for Biomaterials, 42(4), 485-490.

15. Tanzi, M. C., Verderio, P., Lampugnani, M. G., Resnati, M., Dejana, E., \& Sturani, E. (1994). Cytotoxicity of some catalysts commonly used in the synthesis of copolymers for biomedical use. Journal of Materials Science: Materials in Medicine, 5(6-7), 393-396.

16. Nakashima, H., Omae, K., Sakai, T., Yamazaki, K., \& Sakurai, H. (1994). Acute and subchronic inhalation toxicity of tetraethoxysilane (TEOS) in mice. Archives of toxicology, 68(5), 277-283.

17. Kwon, J. S., \& Kim, K. N. (2014). Cytotoxicity evaluation of elastomeric impression materials using different fibroblasts cell lines. Journal of Korean Dental Science, 7(2), 80-86.

18. Kwon, J. S., Lee, S. B., Kim, K. M., \& Kim, K. N. (2014). Positive control for cytotoxicity evaluation of dental vinyl polysiloxane impression materials using sodium lauryl sulfate. Acta Odontologica Scandinavica, 72(8), 618-622.

19. Boraldi, F., Coppi, C., Bortolini, S., Consolo, U., \& Tiozzo, R. (2009). Cytotoxic evaluation of elastomeric dental impression materials on a permanent mouse cell line and on a primary human gingival fibroblast culture. Materials, 2(3), 934944.

20. Javidi, M., Zarei, M., Omidi, S., Ghorbani, A., Gharechahi, M., \& Rad, M. S. (2015). Cytotoxicity of a new nano zinc-oxide eugenol sealer on murine fibroblasts. Iranian endodontic journal, 10(4), 231.

21. Chang-Kyu Kim, H. W. R., Lees, B. D., Minz, K. S., \& Hong, C. U. Evaluation of the radiopacity and cytotoxicity of resinous root canal seaiers. 
22. Nejad, S. M., Özgüneş, H., \& Başaran, N. (2017). Pharmacological and toxicological properties of eugenol. Turk J Pharm Sci, 14(2), 201-206.

23. Meryon, S. D., Johnson, S. G., \& Smith, A. J. (1988). Eugenol release and the cytotoxicity of different zinc oxide-eugenol combinations. Journal of dentistry, 16(2), 66-70.

24. Goiato, M. C., Freitas, E., \& Sonego, M. (2015). Acrylic Resin Cytotoxicity for Denture Base-Literature Review. Advances in clinical and experimental medicine: official organ Wroclaw Medical University, 24(4), 679-686.

25. Kostic, M., Pejcic, A., Igic, M., \& Gligorijevic, N. (2017). Adverse reactions to denture resin materials. Eur Rev Med Pharmacol Sci,21(23), 5298-305.
26. Okita, N., \& Hensten-Pettersen, A. (1991). In vitro cytotoxicity of tissue conditioners. The Journal of prosthetic dentistry, 66(5), 656-659.

27. Atay, A., Cetintas, V. B., Cal, E., Kosova, B. U. K. E. T., Kesercioglu, A., \& Guneri, P. (2012). Cytotoxicity of hard and soft denture lining materials. Dental materials journal,31(6), 10821086.

28. Dorocka-Bobkowska, B., Medyński, D., \& Pryliński, M. (2017). Recent advances in tissue conditioners for prosthetic treatment: A review. Advances in clinical and experimental medicine: official organ Wroclaw Medical University, 26(4), 723-728. 